\title{
Association between cord blood IgE levels in newborns and family history of atopic diseases
}

\author{
Andhika T. Hutapea, Budi Setiabudiawan, Myrna Soepriadi, Diet Sadiah Rustama
}

\begin{abstract}
Background Cord blood-lgE (CB-lgE) levels have been used widely as a specific marker of atopic diseases. In some previous studies, CB-IgE levels in subjects with and without a family history of atopic diseases have been controversial.

Objective To determine the CB-IgE level in newborns and to identify the association between $\mathrm{CB}-\mathrm{IgE}$ and family history of atopic diseases.

Methods A cross-sectional study was done to compare the CB-IgE levels in neonates with or without a family history of atopic diseases in mother, father, or siblings. Subjects of this study were 124 newborns who consecutively born in Puskesmas Kiaracondong, Bandung, during the period of March 2001 to July 2002. Subjects were divided into 2 groups based on history of atopic diseases. Measurements of CB-IgE levels were done by sandwich ELISA methods. Data were analyzed by $c^{2}$ statistics, t test, ANOVA, and Dunkan's test.

Results The mean $\mathrm{CB}-\mathrm{IgE}$ levels in the group with and without a family history of atopic diseases were $3.2 \pm 2.5 \mathrm{IU} / \mathrm{ml}$ and $0.5 \pm 0.5$ $\mathrm{IU} / \mathrm{ml}(\mathrm{P}<0.001)$, respectively. The mean CB-IgE levels in male and female infants with a family history of atopic diseases were $3.3 \pm 2.7 \mathrm{IU} / \mathrm{ml}$ and $3.03 \pm 2.2 \mathrm{IU} / \mathrm{ml}(P>0.05)$, respectively. Based on the cut-off point $(1.3 \mathrm{IU} / \mathrm{ml}), \mathrm{CB}-\mathrm{lgE}$ levels had significant positive association with a family history of atopic diseases (OR 156, $95 \% \mathrm{Cl} 29.61 ; 1104.24)$. CB-IgE levels in neonates with 1, 2, and 3 atopic family members were $1.67 \pm 0.78 \mathrm{IU} / \mathrm{ml}, 3.76 \pm 2.11 \mathrm{IU} / \mathrm{ml}$, and $6.6 \pm 2.7 \mathrm{IU} / \mathrm{ml}$, respectively $(\mathrm{F}=32.603 ; \mathrm{P}<0.001)$.

Conclusion Most newborns with a family history of atopic diseases showed high levels of CB-lgE, but there were no correlation with gender. The probability of having atopic diseases increase in concord with the number of family with atopic diseases [Paediatr Indones 2006;46:199-203].
\end{abstract}

Keywords: cord blood-IgE, newborn, family history of atopic diseases

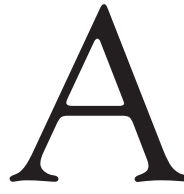

topy is the inherited propensity to respond immunologically to such common naturally occurring allergens with the continuing production of $\operatorname{IgE}$ antibodies. It is specifically associated with the generation of elevated level of IgE antibodies as part of type I hypersensitivity reaction. ${ }^{1-3}$ Atopic diseases are responsible for a wide range of allergic disorders including asthma, atopic dermatitis (AD), rhinitis, urticaria, conjunctivitis, and food allergy. ${ }^{4}$ Family and twins studies showed that both genetics and environmental factors were involved in the atopic diseases. ${ }^{5-9}$ Kjellman et $a l^{9}$ found that the incidence in infants was higher $(72.2 \%)$ if both parents had similar atopic manifestations than one atopic parent.

Results of studies on the association between neonatal $\operatorname{IgE}$ levels and family history of atopic diseases have been varied. ${ }^{10-14}$ Factors that can influence the results are technique in IgE measuremens, differences of cut-off points, and family history definition. The aim of this study was to investigate the From the Department of Child Health, Medical School, Padjadjaran
University, Hasan Sadikin Hospital, Bandung, Indonesia.

Reprint request to: Andhika T. Hutapea, MD, Department of Child Health, Medical School, Padjadjaran University, Hasan Sadikin Hospital, J1. Pasteur 38, Bandung, Indonesia. Tel 62-22-2034426. E-mail: dhikandut@yahoo.com. 
association between the CB-IgE levels in newborns and family history of atopic diseases.

\section{Methods}

This was a cross-sectional study, comparing the CB-IgE levels in neonates with or without a family history of atopic diseases in mother, father, or siblings. Subjects of this study were 124 newborns consecutively born in Puskesmas Kiaracondong, Bandung, during the period of March 2001 to July 2002. Then based on family questionnaire, the subjects were divided into 2 groups, i.e. group of newborns with or without hidtory atopic diseases in their families. The inclusion criteria were healthy babies with spontaneous deliveries and parents agreed to enroll their children in the study and signed informed consent. The exclusion criteria was maternal smoking. The subjects were selected consecutively.

Medical record forms were filled by the authors and trained medical staffs, consisted of mother's name, sex, birth weight, birth height, mother's age, gestational's age, family member with atopic diseases, and IgE. Birth weight and height were measured im- mediately after birth by using baby scale and infantometer. Family history of atopic diseases included asthma, AD, rhinitis, urticaria, and food allergy. The cut-off point of cord blood IgE was $1.3 \mathrm{kU} /$ 1 , based on Croner's study. ${ }^{10}$

Two $\mathrm{ml}$ of cord blood was taken as soon as the baby was delivered by the medical staffs (doctors or midwives) who were in charged for the delivery process. The specimens were measured by Cobas core total $\operatorname{IgE}$, which was a method used to detect the $\operatorname{IgE}$ level with enzyme immunoassay (ELISA) technique in Department of Clinical Pathology, Hasan Sadikin Hospital, Bandung.

All data were recorded, tabulated, and analyzed using SPSS version 11.0. Nominal data analyzed with $\mathrm{c}^{2}$ test, while numerical data were analyzed by t-test or ANOVA and Dunkan's test. $\mathrm{P}<0.05$ was considered statistically significant. The odds ratio (OR) with CI 95\% was calculated as appropriate.

\section{Results}

The characteristics of subjects of both atopic and nonatopic groups are shown in Table 1.

TABle 1. Subject'S Characteristics IN ATOPIC AND NON-ATOPIC GROUPS

\begin{tabular}{lcc}
\hline & \multicolumn{2}{c}{ Group } \\
\cline { 2 - 3 } Characteristics & $\begin{array}{c}\text { Atopic } \\
(\mathbf{n}=62)\end{array}$ & $\begin{array}{c}\text { Non-atopic } \\
(\mathbf{n}=62)\end{array}$ \\
\hline Sex & & \\
$\quad$ Male & $32(51.6)$ & $32(51.6)$ \\
$\quad$ Female & $30(48.4)$ & $30(48.4)$ \\
Birth weight (gram) & & \\
$\bar{X} \pm$ SD & $3053.2(306.1)$ & $3098.4 \pm 346.3$ \\
Median & 3000 & 3050 \\
Range & $2500-3800$ & $2500-4000$ \\
Birth height (cm) & & \\
$\bar{X} \pm$ SD & $49.0 \pm 1.2$ & $48.6 \pm 1.4$ \\
Median & 49 & 49 \\
Range & $47-52$ & $45-52$ \\
Mother's age (year) & $25.9 \pm 5.2$ & $27.2 \pm 5.6$ \\
$\bar{X} \pm$ SD & 25 & 28.5 \\
Median & $17-41$ & $18-38$ \\
Range & & \\
Gestational's age (week) & $38.7 \pm 1.1$ & $38.8 \pm 1.1$ \\
$\bar{X}_{ \pm}$SD & 38.5 & 39 \\
Median & $37-41$ & $37-41$ \\
Range &
\end{tabular}

$\mathrm{n}=$ number of sample; $\bar{x}=$ mean; $\mathrm{SD}=$ standard deviation. 
The mean CB-IgE levels in newborns with and without family history of atopic diseases are shown in Table 2 , while CB-IgE levels in newborns using cutoff point $1.3 \mathrm{IU} / \mathrm{ml}$ are shown in Table 3. father, siblings, or combination) in this study are shown in Table 4. Anova test shows that there is significant association between the number of the family and IgE levels.

TABle 2. The MeAN CORD blOOd-IGE LeVELS IN NEWBORNS

\begin{tabular}{lcclc}
\hline & \multicolumn{3}{c}{ Group } & \\
\cline { 2 - 3 } CB-IgE Levels (IU/mI) & $\begin{array}{c}\text { Atopic } \\
(\mathbf{n}=\mathbf{6 2})\end{array}$ & $\begin{array}{c}\text { Non-atopic } \\
(\mathbf{n}=62)\end{array}$ & $\begin{array}{c}\text { Total } \\
(\mathbf{n}=\mathbf{1 2 4})\end{array}$ & P value \\
\hline Male & & & & \\
$\bar{X}(\mathrm{SD})$ & $3.3(2.7)$ & $0.5(0.5)$ & $1.9(2.4)$ & \\
Median & 2.1 & 0.6 & 1.1 & $\mathrm{t}=0.44$ \\
$\quad$ Range & $1.1-13.4$ & $0-2.2$ & $0-13.4$ & $\mathrm{P}=0.35$ \\
Female & & & & \\
$\bar{X}(\mathrm{SD})$ & $3.03(2.2)$ & $0.6(0.4)$ & $1.8(2.0)$ & \\
Median & 2.3 & 0.5 & 1.2 & \\
Range & $1.1-9.6$ & $0-1.4$ & $0-9.6$ & $\mathrm{t}=9.3$ \\
\hline Total & & & & $\mathrm{P}<0.001$ \\
$\bar{X}(\mathrm{SD})$ & $3.2(2.5)$ & $0.5(0.5)$ & $1.9(2.2)$ & \\
Median & 2.3 & 0.6 & 1.1 & \\
Range & $1.1-13.4$ & $0.0-2.2$ & $0-13.4$ & \\
\hline
\end{tabular}

Table 3. The mean CB-lgE levels in newborns With CUT-OFF POINT $1.3 \mathrm{IU} / \mathrm{ML}$

\begin{tabular}{cccc}
\hline $\begin{array}{c}\text { CB-IgE levels } \\
(I U / m l)\end{array}$ & Atopic & $\begin{array}{c}\text { Non- } \\
\text { atopic }\end{array}$ & \\
\hline $\mathbf{T}$ & $\mathbf{n}$ & $\mathbf{n}$ & $\mathbf{n}$ \\
\hline 1.3 & 52 & 2 & 54 \\
$<1.3$ & 10 & 60 & 70 \\
\hline
\end{tabular}

Table 3 shows that 52/54 (96\%) newborns with $\mathrm{IgE}>1.3 \mathrm{IU} / \mathrm{ml}$ belonged to the atopic group, while only $10 / 70$ (14\%) of those with $\mathrm{IgE}<1.3 \mathrm{IU} / \mathrm{ml}$ belonged to atopic group. There was a significant positive association between IgE levels and family history of atopic diseases (OR 156, 95\%CI; 29.61,1104.24).

CB-IgE levels in newborns based on number of family members with history of atopic diseases (mother,

\section{Discussion}

By using $1.3 \mathrm{IU} / \mathrm{ml}$ as cut off point, we found that IgE-bearing cells have been observed as early as the $11^{\text {th }}$ week of gestation in fetus, yet cord blood contains a little of IgE. The mean IgE levels are higher in the atopic population than those in non-atopic population. ${ }^{1}$ In our study, CB-IgE levels in newborns with a family history of atopic diseases are higher than those in newborns without atopic diseases in their families. There was significant difference between the CB-IgE levels (Table 2). This is consistent with the finding of Croner et al. ${ }^{10}$ Further support to the influence of gender comes from several studies reporting significantly higher CB-IgE levels in males than in females, ${ }^{10} \mathrm{al}$ -

Table 4. Cord blood-IgE In NeWbORns based on the NUMBER OF FAMILY MEMBERS OF FAMILY WITH HISTORY OF ATOPIC DISEASES

\begin{tabular}{lcccc}
\hline CB-IgE levels & $\mathbf{N}(\%)$ & $\bar{X}(\mathrm{SD})$ & Median & Range \\
\hline 1. One atopy & $31(50)$ & $1.67(0.78)$ & 1.4 & $1.39-1.96$ \\
2. Two atopies & $21(34)$ & $3.76(2.11)$ & 3.4 & $2.79-4.72$ \\
3. Three atopies & $10(16)$ & $6.59(2.73)$ & 6.0 & $4.64-8.54$ \\
$\quad$ Total & $62(100)$ & $3.2(2.50)$ & 2.3 & $1.10-13.40$ \\
\hline \multicolumn{5}{c}{$\mathrm{F}=32.603 ; \mathrm{P}<0.001$} \\
\end{tabular}

$\bar{X}=$ mean, $\mathrm{SD}=$ standard deviation 
though conflicting information exists. ${ }^{13,14}$ In our study there was no significant differences between the CBIgE levels in male and female babies (Table 2). This was similar with Velazquez et al's study. ${ }^{13}$

Many differences of CB-IgE cut-off points have been proposed. Our study used cut-off point of 1.3 $\mathrm{IU} / \mathrm{ml}$, based on Croner's study, ${ }^{10}$ that had large samples whereas the other study had no cut-off point as the number of subjects was not enough to make certain cut-off point. Table 3 showed $83.9 \%$ newborns with a family history of atopic diseases have CB-IgE levels $\geq 1.3 \mathrm{IU} / \mathrm{ml}$. According to Croner et al, ${ }^{10}$ atopic diseases developed in $73 \%$ of infants with an initially high CB-IgE levels $(\geq 1.3$ $\mathrm{IU} / \mathrm{m})$ and a family history. This statement will need further investigation that newborns with CB-IgE levels $\geq 1.3 \mathrm{IU} / \mathrm{m}$ have more risks to have atopic diseases in the future than those who have lower CBIgE levels $(<1.3 \mathrm{IU} / \mathrm{ml})$.

Epidemiological studies have established that genetic factors play role in the development of atopic diseases. A negative parental history of atopic diseases is associated with low frequency of atopy in offspring. The risk increases if one the parent has atopy and it becomes higher if the other family member also has atopy. ${ }^{3}$ No significant difference between atopic mothers and fathers was found in our study, but there were significant difference between mean of CB-IgE levels in newborns and the number of family who had atopic diseases histories (Table 4). From the study, babies with $\geq 2$ members of their families that had atopic diseases histories, had higher levels of mean CB-IgE levels compared with only 1 member of their families had atopic diseases histories. This results was similar with Kjellman et al study, ${ }^{9}$ which showed that genetic is one of the factors that play role in atopic disease development. If both parents had atopic diseases histories, the IgE levels of their children were higher than if only one parent had history of atopic diseases.

The characteristic of subjects based on sex, birth weight, birth length, mothers' age, gestational age, did not have significant difference between newborns in atopic and non-atopic groups (Table 1). This was similar with the findings of previous study. ${ }^{13}$

In conclusion, most newborns with a family history of atopic diseases showed high levels of CB-IgE, but there were no correlation with gender. Probabil- ity of having atopic diseases increases in concordance with the number of family with atopic diseases and it still needs further investigation.

\section{Acknowledgements}

We are indebted to the patients and their parents who provided all informations. We thank to Prof. Herry Garna, MD, PhD; Prof. Dedi Subardja, MD; and Prof. Abdurrachman Sukadi, MD, for providing valuable advices, correcting the manuscript, and support which made this study possible.

\section{References}

1. Terr AI. The atopic diseases. In: Parslow TG, Stites DP, Terr AI, Imboden JB, editors. Medical immunology. 10th edition. New York: McGraw-Hill Company; 2001. p. 349-69.

2. Koning H, Baert MRM, Orange AP, Savekoul HFJ, Neijens HJ. Development of immune function, related to allergic mechanisms, in young children. In: Koning $\mathrm{H}$, editor. $\mathrm{T}$ and $\mathrm{B}$ cell activation in childhood allergy. Roterrdam; 1996. p. 11-30.

3. Yadav M. Maternal factors in atopy. Medical progress. March 2000:15-22.

4. Kay AB, Mackay IR, Rosen FS. Allergy and allergic diseases. N Engl J Med 2001;1(344):30-7.

5. Hopkin JM. Genetics of atopy. Pediatr Allergy Immunol 1995;6:139-44.

6. Kjellman NAM, Johansson SGO. IgE and atopic allergy in newborns and infants with a family history of atopic diseases. Acta Pediatr Scand 1976;65:601-7.

7. Savelkoul HFJ, Neijens HJ. Immune responses during allergic sensitization and the development of atopy. Allergy 2000;55:989-97.

8. Jones CA, Holloway JA, Warner JO. Does an atopic disease start in foetal life?. Allergy 2000;55:2-10.

9. Kjellman NAM, Johansson SGO. IgE and atopic allergy in newborns and infants with a family history of atopic diseases. Acta Pediatr Scand 1976; 65:601-7.

10. Croner S, Kjellman NIM, Eriksson B, Roth A. IgE screening in 1701 newborns infants and the development of atopic diseases during infancy. Arch Dis Child 1982;57:364-8.

11. Edenharter G, Bergmann RL, Bergmann KE, Wahn V, Fostr J, Zepp F, et al. Cord blood IgE as risk factor and 
Andhika T. Hutapea et al: Cord blood IgE levels in newborns and family history of atopic diseases

predictor for atopic diseases. Clin and exp allergy 1998;28:671-8.

12. Eiriksson TH, Sigurgeisson B, Sigfusson A, Valdimarsson H. Cord blood IgE levels are influenced by gestational age but do not predict allergyc manifestations in infants. Pediatr Allergy Immunol 1994;5:5-10.
13. Velazquez PSV, Angeles MB. Concentraciones de IgE en sangre de cordon umbilical y su asociacion con factores de riesgo atopico. Educ Invest Clin 2000; 1(3):172-6.

14. Atici A, Altintas D, Yuksel B, Evliyaoglu N, Evruke C, Satar M, et al. Do parental smoking and history of allergy influence cord serum IgE?. Pediatr Allergy Immunol 1995;6:213-5. 